\title{
Tobacco industry successfully prevented tobacco control legislation in Argentina
}

\author{
E M Sebrié, J Barnoya, E J Pérez-Stable, S A Glantz
}

Tobacco Control 2005;14:e2 (http://www.tobaccocontrol.com/cgi/content/full/14/5/e2). doi: 10.1136/tc.2005.011130

See end of article for authors' affiliations .....................

Correspondence to: Stanton A Glantz, PhD, Box 1390, CL 366, San Francisco, CA 94143, USA; glantz@medicine. ucsf.edu

Received 7 January 2005 Accepted 8 June 2005
Objective: To evaluate how transnational tobacco companies, working through their local affiliates, influenced tobacco control policymaking in Argentina between 1966 and 2005.

Methods: Analysis of internal tobacco industry documents, local newspapers and magazines, internet resources, bills from the Argentinean National Congress Library, and interviews with key individuals in Argentina.

Results: Transnational tobacco companies (Philip Morris International, British American Tobacco, Lorillard, and RJ Reynolds International) have been actively influencing public health policymaking in Argentina since the early 1970s. As in other countries, in 1977 the tobacco industry created a weak voluntary self regulating code to avoid strong legislated restrictions on advertising. In addition to direct lobbying by the tobacco companies, these efforts involved use of third party allies, public relations campaigns, and scientific and medical consultants. During the 1980s and 1990s efforts to pass comprehensive tobacco control legislation intensified, but the organised tobacco industry prevented its enactment. There has been no national activity to decrease exposure to secondhand smoke.

Conclusions: The tobacco industry, working through its local subsidiaries, has subverted meaningful tobacco control legislation in Argentina using the same strategies as in the USA and other countries. As a result, tobacco control in Argentina remains governed by a national law that is weak and restricted in its scope.
A rgentina has made the epidemiological transition to an advanced stage in the tobacco epidemic and the Southern Cone region of the Americas leads the hemisphere in tobacco attributable mortality. ${ }^{1}$ Argentina is a developing country with economic interests in tobacco growing and rapidly increasing tobacco use in urban areas. In 2000, smoking prevalence was $40.4 \%$ among adults ${ }^{2}$ (compared to $23.6 \%$ in the USA ${ }^{2}$ ), 30 day prevalence among urban youth (13-15 years old in Buenos Aires) was $30.2 \%^{3}$ (compared to $17.7 \%$ in the USA ${ }^{4}$ ), prevalence among health professionals was $30.3 \%$ among physicians, and 36.3\% among nurses $^{5}$ (compared to $3.3 \%$ and $18.3 \%$ in the USA, ${ }^{5}$ respectively). In addition, the percentage of young people (13-15 years old) exposed to secondhand smoke (SHS) in Buenos Aires was $69.6 \%$ at home, $87.6 \%$ in public places, and $27.6 \%$ from their friends. ${ }^{3}$ Buenos Aires had the highest airborne nicotine levels inside hospitals, schools, government buildings, airports, and restaurants among seven Latin American cities in $2002 .^{6}$

Argentina has been politically unstable with periods of military dictatorships that made laws by decree; the return of democracy in 1983 reintroduced independent branches (executive, legislative, and judicial). Political power, however, has been concentrated in the presidency. The National Congress is responsible for passing federal laws that must be signed or vetoed by the president.

By the late 1970s, two transnational tobacco companies (TTC) dominated the cigarette market in Argentina: British American Tobacco (BAT), through its subsidiary NoblezaPiccardo (N-P), and Philip Morris International (PMI), through Massalín-Particulares (M-P).-9 In addition, Lorillard Tobacco, ${ }^{10}$ and RJ Reynolds Tobacco International ${ }^{11}$ entered the market in 1971 and 1981 through licensing agreements.

In addition to the USA and Britain, the TTC's strategies ${ }^{12}$ to prevent tobacco control legislation have been described in other developing countries (for example, Hungary, ${ }^{13}$ Malaysia, ${ }^{14}$ Philippines, ${ }^{15}$ Singapore, ${ }^{16}$ Thailand ${ }^{17}$ ) and developed countries (for example, Australia, ${ }^{18}$ Finland, ${ }^{19}$ Germany, ${ }^{20}$ Hong Kong ${ }^{21}$ ). Despite the economic and cultural differences between Argentina and these countries, TTC have used their Argentinean affiliates to implement similar strategies as elsewhere to block meaningful tobacco control.

\section{METHODS}

Between October 2003 and April 2005 we searched tobacco industry documents in the University of California San Francisco (UCSF) Legacy Tobacco Documents Library (http:// legacy.library.ucsf.edu), the British American Tobacco Documents Archive (http://bat.library.ucsf.edu), and Tobacco Documents Online (http://tobaccodocuments.org/). Initial search terms were geographical names, Argentinean politicians and public health leaders, specific dates, TTC subsidiaries, project names, and reference (Bates) numbers near relevant documents. After identifying the first documents or words, we used a snowball strategy to locate new documents. A total of about 230 relevant documents were found.

\footnotetext{
Abbreviations: BAT, British American Tobacco; COMFER, Comité Federal de Radiodifusión (Federal Radio Broadcasting Committee); CTI, Chamber of Tobacco Industry; ETS, environmental tobacco smoke; FCTC, Framework Convention on Tobacco Control; FDA, Food and Drug Administration; ICOSI, International Committee on Smoking Issues; LALCEC, Liga Argentina de Lucha Contra el Cáncer (Argentinean League Against Cancer); M-P, Massalín-Particulares; N-P, NoblezaPiccardo; PM, Philip Morris; PMI, Philip Morris International; PMLA, Philip Morris Latin America; SHS, secondhand smoke; TTC, transnational tobacco companies; UATA, Unión Anti-Tabáquica Argentina (Argentinean Anti-Tobacco Union); UCSF, University of California San Francisco; US, United States; WHO, World Health Organization
} 
We also used internet resources, major Argentinean newspapers, magazines, and the Argentinean National Congress Library.

We conducted interviews with congressmen, public health officials, and tobacco control advocates in Buenos Aires during December 2003. Interviews were conducted using a semi-structured format according to a protocol approved by the UCSF Committee on Human Research.

A report providing details of the legislative history summarised in this paper, as well as more extensive material from the tobacco industry documents and interviews, is available in the University of California Scholarship repository. ${ }^{22}$

\section{RESULTS}

\section{Tobacco control legislation from 1966 to 1992} First attempts (1966-1974)

The first bill to regulate tobacco was proposed in 1966, to place a health warning label on cigarette packages, motivated by the fact that the USA ${ }^{23}$ had adopted such a measure. It did not pass. ${ }^{24}$

In 1970, a military government promulgated Law 18.604 ending cigarette advertising on radio, television, and in movie theatres ${ }^{25-27}$ for one year..$^{28}$ Both US health authorities ${ }^{29}$ and the $\mathrm{TTC}^{30}$ recognised that the government was responding to pressure by local tobacco producers to curb the increasing threat of foreign commercial competition, rather than health concerns.

The first documented involvement of the TTC in blocking tobacco control legislation came in 1973, when a bill was introduced that would have required a warning label on cigarette packages with fines from violators used to promote alternative crops and industries. ${ }^{31}$ According to N-P, "the Chamber of Tobacco Industry (CTI) [Cámara de la Industria del Tabaco, the Argentinean national tobacco manufacturers' association] intervened informally and kept the bill from being approved". ${ }^{32}$ When a new bill was introduced in 1974 to require a warning label and some advertising restrictions, ${ }^{33}$ lawyers from Lorillard Tobacco in New York and the law firm Merval \& O'Farrell in Buenos Aires monitored it. ${ }^{34-37} \mathrm{~A}$ Lorillard representative in Buenos Aires ${ }^{38}{ }^{39}$ reported to New York that they had stopped filming the new Kent commercials, "until a final decision on the effectiveness of this law is reached by Congress" ${ }^{\prime 38}{ }^{39}$ The bill passed the Senate, ${ }^{40}$ but the Lower House did not approve it.

\section{The tobacco industry advertising code of practice (1977)}

In 1977, the CTI created its Smoking and Health Advisory Committee (later renamed the Smoking Controversy Department and Permanent Committee), which produced press articles with industry arguments, working papers on medical-scientific aspects of tobacco and health, ${ }^{41}$ and a "Self-regulated Advertising Code" to "restrict" cigarette advertisements $^{32}$ from being directed at youth (under 21) through publications or events. According to CTI President Alberto Rubio the "Code sponsored for all commercial activities by the National Advertisers' Association, was endorsed by the country's authorities". ${ }^{32}{ }^{42-44}$ Creating such a voluntary codes has been a common TTC strategy used to prevent the enactment of stronger anti-tobacco legislation in many countries ${ }^{45}{ }^{46}$ while not reducing smoking. ${ }^{47-52}$

The Ministry of Social Welfare bills (1976-1979) Two bills were drafted between 1976 and 1979 by the Ministry of Social Welfare to restrict content of alcohol and tobacco advertisements and require a warning label. The CTI offered its code as an alternative to the proposal which stopped the first bill. ${ }^{41}{ }^{42}$ The CTI also successfully lobbied government officials against the 1979 bill introduced in response to the World Health Organization's (WHO's) international "Smoking or Health," arguing that several governmental initiatives on the same issue were creating confusion and overlapped with their established code. ${ }^{41} 42$

The TTC discussed these experiences at a 1980 meeting in Frankfurt, Germany, of their International Committee on Smoking Issues (ICOSI), the international equivalent of the US Tobacco Institute, which was formed around 1977 to coordinate their responses to the emerging tobacco control movement. ${ }^{53}$ (ICOSI was renamed INFOTAB ${ }^{54}$ and, later, Tobacco Documentation Center ${ }^{55}$ ). CTI's report, "The situation in Argentina regarding attempts to restrict publicity", 425657 was presented in the session "How do we Prevent Advertising Restrictions?". 425657

Increasing organisation by the CTI (early 1980s)

During the 1980s CTI began a campaign to influence the public opinion and gain political support, as Rubio reported at the 1980 ICOSI meeting:

[CTI] put in motion a nation-wide campaign directed to public opinion including widespread counter-information (consisting of the distribution of comments, articles and scientific papers provided by ICOSI, the [US] Tobacco Institute, the [US] Council of Tobacco Research, our associate manufactures and material prepared by ourselves), an institutional campaign to make known our selfrestraint in publicity [the Self-regulated Advertising Code] and another for the sector's image to achieve a greater political space for our action. ${ }^{42}$

A 1981 PMI internal Corporate Affairs Status Report emphasised the importance of having regular contacts with public officials, the military, and the media to avoid advertising restrictions. ${ }^{58}$

During 1982-83, the CTI organised "Information Seminars on the Smoking Controversy" for tobacco company managers, agricultural technicians, and the medical and scientific community. ${ }^{59}$ As elsewhere in the world, the CTI communication strategy for the medical community was to attack the scientific evidence on the health dangers as flawed. Another seminar was planned for journalists, tobacco advertising agencies, tobacco products distributors, candidates for public office, representatives, senators, and Ministers of Health..$^{50}$

At a 1983 INFOTAB meeting in Washington, DC, Rubio described Argentina's anti-tobacco movement:

\section{SITUATION}

- Scarce institutionalization of antismoking groups

- Unsuccessful efforts to pass restrictive legislation

- Good image of the NMA [national manufacturer association] which is taken into account and enjoys credibility because it deals with qualified and objective information

POSSIBILITIES

- To use medical-scientific arguments to weaken the campaign foundations

- To act directly as a sound speaker before authorities and antismoking groups ${ }^{59}$

A 1983 Brown \& Williamson report described INFOTAB Secretary General's visit to Buenos Aires to meet with BAT, PMI, and CTI representatives who were extremely concerned about the new elected government and specifically the possibility that Dr Carlos Alvarez Herrera, "the head of the 
Anti-Smoking movement" ${ }^{16}$ would be appointed Minister of Health. ${ }^{61}$

\section{Lost opportunities: three legislative proposals} (1984-1996)

October 1983 marked the return of democracy to Argentina and President Raúl Alfonsín nominated Dr Aldo Neri as Minister of Health (1983-1986). Neri appointed Alvarez Herrera (Liga Argentina de Lucha Contra El Cáncer [LALCEC], Argentinean League Against Cancer campaign coordinator) president of the newly created government agency Comisión Coordinadora y Asesora sobre Tabaquismo (Coordinating and Advisory Committee on Smoking). ${ }^{32}$

A 1984 PM visitor to Argentina reported:

An industry-government committee has been formed to discuss labeling and publication of tar and nicotine numbers. Mario Bugna [Technology Group Director, M$\mathrm{P}]$ is the industry's representative on this committee.... A warning label is forthcoming in about six months under the auspice of the Health Ministry. Tar and nicotine numbers will be generated, however under the Agriculture Ministry. There is some confusion because the National Health Laboratory (equivalent to our [US] Food and Drug Administration [FDA]) is now under the Public Health Ministry. ${ }^{62}$

Repeating a strategy that the tobacco industry used in the USA and elsewhere, in March 1984, the CTI published a leaflet on the tobacco industry's economic impact in Argentina, summarising "its contribution to the national economy". ${ }^{63}$ Copies were distributed to all national legislators, journalists, members of the Armed Forces, economists, and provincial authorities, newspapers, and magazines. The leaflet led to sympathetic articles in an Argentine business magazine and a publication for legislators. ${ }^{6465}$

In May 1984, the Secretary of Commerce enacted Ruling 422 placing some restrictions on tobacco advertising, prohibiting models younger than 21 years old and the association of smoking with any type of sports or physical activity. ${ }^{66}$ The industry was not concerned because "most of these restrictions, however, had already been in force de facto since 1977 under the terms of a self-regulation agreement [the industry code]". ${ }^{67}$ By 1984, public health officials began to propose restrictions on tobacco advertising that were dominating television and targeting young people. ${ }^{68}$ Three proposed bills during this time particularly worried the tobacco industry: the Maglietti, the Neri, and the Pepe bills.

In June 1984, Representative Alberto Maglietti introduced a comprehensive bill to severely restrict tobacco advertising and sponsorship, place strong rotating health warning labels and constituent disclosure on cigarette packages, and establish smoke-free public places. ${ }^{69}$ INFOTAB tracked the bill's evolution and reported that "company lawyers have jointly written a response to the Maglietti Bill (INFOTAB gave extensive help in gathering relevant material) $)^{\prime \prime}{ }^{70}$ A CTI presentation "Responding to a Government Bill" was made at the 1985 INFOTAB Second Latin American Workshop held in Miami. ${ }^{71}$ The industry marshalled its standard arguments that any limitations on "the freedom to advertise" would be an unacceptable infringement of rights to prevent the bill from coming to a vote.

In 1985, Minister of Health Neri drafted a tobacco control bill that would almost completely end advertising, sponsorship, and smoking in most public places. ${ }^{72-74}$ The US trade newspaper Advertising Age described tobacco companies' and local advertising agencies' strong opposition to the bill:
"If passed, it will be the most severe tobacco law on the planet Earth" said a worried Pablo Galli, Camel's account director with [advertising agency] McCann Erikson here [Argentina].

... Last year Argentina's two leading cigaret marketers, Nobleza Piccardo (British American Tobacco) and Massalin Particulares (Philip Morris), spent about \$11 million on advertising. The agencies include Leo Burnett Co., J. Walter Thompson Co. and most of Argentina's top shops. "We'll try to stop it, but if it gets into congress we will launch a campaign to tell the population there is no direct relation between advertising and cigarette consumption, according to research by the International Advertising Assn..", said Pablo Gowland, president of Gowland Publicidad. The agency handles Nobleza Piccardo's market leader Jockey Suaves, and Conway. ${ }^{75}$

Both RJ Reynolds ${ }^{44}$ and PM closely monitored Neri's and public health advocates' efforts to enact the bill, while also noting that the media were willing to accept increasing numbers of cigarette ads. ${ }^{76-78}$

The same year Argentinean lawyer Alberto Kattan sued the Comité Federal de Radiodifusión (COMFER, Federal Radio Broadcasting Committee), the committee that supervises radio and television broadcasting. The lawsuit argued that such radio and television cigarette advertising was illegal because it violated norms that prohibit broadcasting messages harmful to listeners' health. Soon after, advertising agencies PRAGMA Publicidad (for N-P), and RADIUX Publicidad (for M-P), filed an opposing petition as third parties affected by the lawsuit. In February 1986, the judge ruled in favour of Kattan; COMFER, PRAGMA, and RADIUX immediately appealed, preventing the implementation of the initial ruling. ${ }^{79-81}$

In August 1986, a bill introduced by Representative Lorenzo Pepe was approved as Law 23.344. The law ${ }^{82}$ mandated the warning "Fumar es perjudicial para la salud" (Smoking is harmful to health) on tobacco products and put restrictions on advertising that were much weaker than the original 1984 proposal. ${ }^{83}$ N-P explained: "After intense activities before different Senators, the CIT [sic CTI] finally succeeded in having the project modified to practically coincide altogether with the Auto-Regulated Code which had been prepared by Industry." ${ }^{32}$ As part of the CTI's "strategies to counter the threats faced by the industry",, industry representatives met with the Ministers of Interior and Economy, Secretaries of Public Health, Agriculture, Commerce, and Treasury, Governors and provincial ministers. $^{32}$

After Law 23.344 was approved, the Court dismissed the Kattan's lawsuit against the COMFER and the Neri Bill was shelved.

In October 1986, N-P Corporate Affairs Director presented "How Argentina developed strategies to get an Advertising Law compatible with their Self-Regulation Code" at the INFOTAB International Workshop in Brussels. He identified public health organisations and selected health care institutions as "enemies" and Senators from tobacco growing provinces as "allies" 84 and explained how the Pepe Bill was modified to mirror CTI's code:

It happened that these circumstantial industry allies were all in the Senate. Therefore we were forced to mark time (which we did very actively!) until the Chamber [Lower House] approved a Bill, to then support in the Senate those whose fundamental ideas coincided with our own, in order to secure the modification of the original Bill, 
approval in committee, and definitive approval as modified.

All this strategy was based on the fact that the points on which legislation was desired had already been included in the self-regulatory code which the industry had been working with for many years.

The final result was the Senate approval of a modified Bill with the Chamber later approved without any modification and which follows our self-regulatory code. ${ }^{84}$

The industry successfully used Law 23.344 not only to end the legal challenge to broadcast advertising, but to prevent a ban on tobacco advertising and to block other legislation that could have affected industry's profits. ${ }^{85}$ As one observer noted:

Actually there are reasons to suppose that this law is a tactic to defend the tobacco companies' interests, pretending to fight against them. In fact, law 23.344 when it prohibits tobacco advertising during the "minor protection hours," [between 8 am and 10 pm] actually is allowing it during the remaining hours. That is to say, it is a way to prevent to apply the norms that bans to broadcast harmful messages. On the other hand, minors who go to sleep at $10 \mathrm{pm}$ are at the most 9 or 10 years old, and they do not represent the cigarette market. But for adolescents, this could be an additional reinforcement when getting the advertising in a for-adult hour. For the companies, to focus their advertising at that time, means just a saving of money. ${ }^{79}$ [translated by the authors]

Several amendments were proposed to strengthen Law 23.344, such as penalties for violations, but CTI stopped them. ${ }^{32} 8687$

The Neri Bill's second try (1990-1992): a law with 10 days of life

In May 1990, now-Representative Aldo Neri introduced a comprehensive tobacco control bill ${ }^{88}$ drafted by Alvarez Herrera with assistance from WHO while Neri was Minister of Health. It passed the Lower House in September among nearly 200 other bills on the last day of the regular legislative sessions without any amendments and was forwarded to the Senate. ${ }^{89} 90$

PM's strategies to "attempt to prevent it from being passed" ${ }^{\prime 91}$ in 1991 included the distribution of an extensive report to legislators, listing "all the negative aspects and contradictions such bill involves" ${ }^{87}$

In April 1992, organised by the Unión Anti-Tabáquica Argentina (UATA, Argentinean Anti-Tobacco Union), with support from WHO, the American Cancer Society, and the UICC, the 8th World Conference on Tobacco or Health was held in Buenos Aires, the first time in a developing country. While local tobacco control advocates took the opportunity to support the Neri Bill, PM and BAT worked to divert the attention from the conference by organising briefings with friendly journalists to create controversy about SHS and health. ${ }^{87}$ 92-122

According to PM Latin America's (PMLA) vice-president, on 25 September 1992, Provisional President of the Senate Oraldo Britos "called a surprise meeting with representatives of advertising agencies, the media and the tobacco industry to discuss the disposition of the bill during which he exerted strong pressures on those who attended [emphasis added]". ${ }^{89}$ According to news reports, ${ }^{89}{ }^{123-126}$ Britos requested a "contribution" of \$1 million to shelve the bill and, when he did not succeed, scheduled the bill for a Senate vote on 30
September 1992, the last day of the session..$^{89}$ The bill passed the Senate despite strong opposition from Senator José Romero Feris (former Governor of Corrientes, a tobacco growing area). ${ }^{127-130}$

After Congress passed the bill, the industry worked "to create an atmosphere in which a presidential veto would be politically feasible". ${ }^{89}$ The CTI wrote to President Carlos Menem requesting a veto and tobacco industry representatives contacted government officials including the Minister of Economy Domingo Cavallo. Governor of Salta Roberto Ulloa, and other governors of the tobacco growing provinces sent letters supporting a veto. ${ }^{89}$ The industry also mobilised a major media offensive, including television and radio interviews and paid advertising. ${ }^{89}$ On 5 October, PM organised in Buenos Aires "a closed door working session with the media owners, sports figures, advertising executives, and other interested parties, to initiate a campaign in favor of a presidential veto" 89131 of the bill. Letters were sent to President Menem by the International Advertising Association, the Interamerican Press Association, and the Interamerican Society for Freedom of Commercial Speech, and advertising agencies with offices in Argentina, requesting a veto. ${ }^{89}$ Repeating arguments that TTC used elsewhere against advertising restrictions, the Argentine Association of Advertising Agencies stated that restricting cigarette advertising could begin a cascade of events that would undermine "free expression" regarding other products. ${ }^{89}$

On 30 September, a public opinion poll in Buenos Aires was commissioned by the tobacco industry and taken by Tele Survey, the firm President Menem used for his own polls. The result that $71 \%$ of 255 respondents "supported" the veto were publicised in major Buenos Aires newspapers, ${ }^{132}$ television and radio news, and sent to President Menem. ${ }^{89}$

Carlos Alvarez, a cardiologist, professor at the Catholic University of Argentina, and director of the Cardiovascular Clinics Institute at Buenos Aires, was a tobacco industry consultant used as part of its secret lawyer managed "Latin Project". ${ }^{133}$ Alvarez also served as a technical and scientific advisor to President Menem and lobbied him to veto the bill. ${ }^{133}{ }^{134}$ Alvarez wrote to a tobacco industry lawyer requesting $\$ 20000^{135-137}$ for five working days lobbying members of the Senate and President Menem. According to the lawyer:

\section{Dr. Alvarez's activities included conversations with Senators from both parties and a series of conversations with President Menem as well as President Menem's brother, who serves as President of the Argentine Senate. Dr. Alvarez also provided President Menem with a briefing package and covering letter that pointed out that the smoking restrictions that had been proposed lacked a solid scientific basis. ${ }^{138}$}

On 13 October, Menem vetoed the Neri Bill.

Menem's previous association with PM may have been another factor in his decision. According to the Argentinean magazine Humor, Menem may have received money ("una suculenta colaboración", a substantive collaboration) from PMI during his presidential campaign in $1988-89 .{ }^{139}$

PMI concluded that "a quick and effective response is facilitated by having a prepared set of arguments, international precedents and legislative proposals" ${ }^{89}$ PMI was also concerned about the consequences that the law, if passed, could have had in other countries in the region. Rodríguez (PMLA) distributed a summary of the Argentina case to all PMI representatives of the world, highlighting the "lessons learned": 
The impact of anti-tobacco legislation may have a domino effect in neighboring countries. Congressional approval of restrictions such as those contained in Argentina's Neri Bill can inspire other governments in the region to adopt similar legislation. Similarly a president veto in one country can influence initiatives in nearby countries. For example, a longstanding proposal to severely restrict tobacco advertising in Paraguay was rejected by the Senate in the week following President Menem's veto of the Neri Bill. In the same week, a proposal of the same nature in Venezuela's congress was temporarily shelved. Regional economic integration movements, such as MERCOSUR [the Southern Common Market made up by Argentina, Brazil, Uruguay, and Paraguay], can accelerate the domino effect. ${ }^{89}$

PMI was right.

\section{Tobacco control legislation from 1992 to 2005: the post-veto era \\ The tobacco industry alternative bills}

After securing the Neri Bill veto, the industry started to prepare new legislation as "a constructive counter-propo$\mathrm{sal}^{\prime \prime 89}$ to protect their interests. According to PMLA's vice president," [the] tobacco industry maintained frequent contact with Senate Health Committee to discuss alternative proposals which culminated in the preparation of substitute bills by several senators for consideration by the committee" ${ }^{\prime \prime}{ }^{89}$ Three bills were supported by the tobacco industry: the Molina, the Ulloa, and the Mazza bills.

In November 1992, Senator Pedro Molina, President of the Public Health Committee, introduced an "alternative bill" in the Senate that was consistent with the industry's voluntary advertising code and, rather than mandating smoke-free environments, established areas for smokers and nonsmokers in public enclosed buildings. ${ }^{140}$ According to an M-P report:

This draft was obtained by consensus with Congress, through the Tobacco Industry Association [CTI] (PM and BAT) jointly with advertising agencies, media associations and previous PMI advice.

It is consistent with PMI marketing code and tobacco industry's self regulating principles.

The Molina Law is a positive improvement concerning antismoking regulations, marketing freedom and access to media, when compared with the vetoed Neri Law. ${ }^{141}$

The bill was not voted on and died in March 1994. In May 1994, Molina reintroduced the bill, which passed the Senate in November 1995. ${ }^{142}$

In August 1995, Representatives Pepe and José Corchuelo Blasco introduced another pro-health bill requiring mandatory disclosure of nicotine and tar levels on all tobacco containers. ${ }^{143}$ In 1996, the Lower House passed this bill and rejected the pro-industry Molina Bill. While both bills were being considered in the Congress, in October 1996, N-P held a press conference on "Regulatory Framework of Tobacco in Argentina" in Buenos Aires, to launch a new cigarette brand with nicotine and tar content disclosure on packages (later extended to all their brands). According to N-P, this unilateral voluntary measure was adopted anticipating possible approval of new tobacco legislation under discussion in the Congress, ${ }^{144-163}$ which did not happen. This action may have been a new tactic of the tobacco industry to block the approval of meaningful tobacco control legislation. In 1997, the Senate rejected the Pepe \& Corchuelo Blasco Bill, because they supported the competing Molina Bill. ${ }^{143} 164$

In 1998-2000, Senator Roberto Ulloa (former Governor of Salta) unsuccessfully reintroduced the Molina Bill. ${ }^{165}$ The Secretary of the Senate Public Health Committee recognised the bill as an effort to protect tobacco marketing:

The Province of Salta is one of the largest producers of tobacco in the country. ... [Ulloa wanted the bill] because it was a way to definitively legalize all tobacco advertising and commerce .... to prevent the Argentinean industry to become susceptible to sanctions like in the US, or lawsuits for civil liability, for cancer deaths, etc., so by having a law tobacco marketing activity was more protected. In fact, legally recognized. ${ }^{164}$ [translated by the authors]

Minister of Health Dr Alberto Mazza also introduced a bill ${ }^{166}$ in 1998 that was similar to the Molina Bill, weak and consistent with the industry's code. ${ }^{164} 167168$ The bill died in the Senate without being considered.

Other efforts to displace meaningful tobacco control (mid 1990s)

In addition to opposing legislation, TTC promoted voluntary "accommodation" as part of its programme to diffuse the SHS issue, to avoid legislation and maintain the social acceptability of smoking. Since the mid 1990s the regional project "La Cortesía de Elegir" (The Courtesy of Choice), also known as "Convivencia en Armonía" (Coexistence in Harmony), has been developed in Argentina and most Latin America countries to avoid smoking restrictions in the hospitality sector (similar to the PM "Accommodation Program" created in the late 1980s in the USA ${ }^{169170}$ ). Launched in Argentina by PM in 1995, and supported by the International Hotel \& Restaurant Association and the local Federación Empresaria Hotelera-Gastronómica de la República Argentina (Argentinean Hospitality Industry), BAT joined efforts in 1997. ${ }^{171} 172$

The industry also sought to pre-empt meaningful antitobacco education with its own "youth smoking prevention" programmes. The PMI's five point "Youth Access Prevention \& Education Programs" ${ }^{\prime 46}$ 173-182 (including local marketing codes, sampling guidelines, minimum age of purchase laws, education and retailer programmes) were developed for Latin America by 1997, to shift the focus away from the industry's advertising and marketing (as in other countries ${ }^{183}$ ).

"Yo Tengo P.O.D.E.R." (I have the Power), a "broad-based youth education program intended for educators to help children handle peer pressure", ${ }^{180}$ was launched in 1997 in Argentina with the endorsement of the Ministry of Education and CONCIENCIA (consciousness), a local non-profit educational organisation. ${ }^{46}{ }^{134}{ }^{184}$ In 1998, CTI started the retailer programme "Yo NO Vendo Cigarillos a Menores de 18 Años" (I do not sell cigarettes to minors under 18), equivalent to the 1995 US "We Card", ${ }^{183}$ a programme targeted at convenience stores. ${ }^{180}$

Mirroring positions taken by PM in the USA, ${ }^{185} 186$ and BAT in the UK, ${ }^{187}$ the Argentinean CTI released a new version of its self regulation code in 1997. ${ }^{188-193}$

Another version of the CTI's code was issued in June 2001. ${ }^{194}$ A warning text, similar to the one on cigarette packages (the only place required by law), would be placed in all types of publicity such as television, radio, cinema, print media, and outdoor billboards. A CTI's Self-regulating Committee was created to "enforce" the code. ${ }^{194}$ In 2001, the CTI adopted the International Marketing Standards for Tobacco Products developed by BAT, PM, and Japan Tobacco. ${ }^{195}$ 
The Garré Bill (1998)

In June 1998, Representative Nilda Garré introduced a bill requiring total disclosure of ingredients and additives in the tobacco products, among other measures. ${ }^{196} \mathrm{PM}$ was concerned, concluding that "the legislative draft reproduces the most severe arguments related to tobacco issues originated by the WHO and the FDA" ${ }^{\prime 197}$ PM monitored the bill from New York" 198199 and sent the "PMI Guidelines on Public Policy Issues" to M-P's communications manager in Buenos Aires to use "in devising strategies to address various proposals emanating from policymakers". 186200201

PM in New York prepared a detailed response to the issues addressed by the Garré Bill that mirrored the standard positions taken by the TTC. The company claimed that additives were used mainly as flavourings and that it needs to "preserve the value of its confidential trade secrets so it can distinguish its brands from those of its competitors". ${ }^{202} 203$ The response to SHS repeated standard industry rhetoric on "accommodation"170 and promoted ventilation as an alternative to smoke-free areas: ${ }^{204}$

\section{...solutions designed to minimize uncomfortable or annoying exposure to ETS [environmental tobacco smoke] by nonsmokers...may include ventilation, separation, special lounges, breaks and convenient and comfortable indoor and outdoor smoking areas. ...opposes the imposition of unreasonable smoking restrictions or bans in public places or the workplace. ...enthusiastically supports reasonable voluntary and regulatory measures to accommodate the preferences of both smokers and nonsmokers. ...providing separate smoking and non- smoking areas... ${ }^{203}$}

To oppose the Garré Bill, PM in New York also sent $\mathrm{M}-\mathrm{P}$ the US cigarette labelling law $^{205}$ that, while requiring tobacco companies to provide a list of the ingredients added to tobacco in the manufacture of cigarettes to the Secretary of Health and Human Services, did not permit the Secretary to release any of this information to the public ${ }^{206-208}$; and the "PM USA response to Chairman [of the US House Commerce Committee Tom] Bliley regarding ammonia and the bioavailability"209 stating that PM adds ammonia compounds as processing aids and flavourings, and denying that this additive could increase the amount of nicotine absorbed or delivered to the smoker's brain. ${ }^{210}$ The bill was not approved.

\section{The Neri Bill's new attempt 10 years after the veto (2002-2005)}

During 2002-2003 at least 18 tobacco control bills ${ }^{211-228}$ were introduced in the Lower House including one by Representative Neri in September 2002. This bill was similar to the one vetoed in 1992. In 2003, the Lower House Public Health Committee drafted a version that consolidated all 18 bills into one that included pro-health provisions, and forwarded it to 12 other Congressional Committees. On 4 November 2003 Representatives from the 13 committees, the Minister of Health, public health officials, and representatives of both tobacco subsidiaries (M-P \& N-P), were scheduled to meet in the Congress to discuss the proposals. Surprisingly, the Budget and Treasury Committee's officials "could not participate" and the meeting was postponed indefinitely, 229 a victory for the tobacco industry that succeeded in tabling the bills. ${ }^{230}$

In July 2004, Neri introduced the bill again ${ }^{231}$; as of July 2005 there had been no action on the bill.

\section{The Framework Convention on Tobacco Control}

International efforts for tobacco control have been focused in 2003-4 on the signing and ratification of the Framework Convention on Tobacco Control (FCTC), the first worldwide public health treaty. ${ }^{232}$ Argentina opposed the treaty during the negotiations, ${ }^{233}$ and its delegation included a representative of the Secretary of Agriculture, who was a "staunch defender of the tobacco producers". ${ }^{234} 235$

At the same time, a 2001 urban survey conducted in Argentina showed strong public support (93\%) for tobacco smoking restrictions. ${ }^{236}$ On 25-26 August 2003, an International Meeting on Tobacco Control was held in Buenos Aires supported by the Ministry of Health, to discuss the implications of the FCTC in Argentina and the MERCOSUR ${ }^{230}$ and highlighting the treaty as "a historical opportunity" to promote tobacco control policies. Attendees included WHO, Pan American Health Organization, World Bank, MERCOSUR, Bolivia, and Chile. ${ }^{237}$ On 25 September 2003, President Néstor Kirchner and Minister of Health Dr Ginés González García signed the FCTC. In October 2003,238239 legislators drafted bills to ratify the treaty and in June 2004, the Executive Branch introduced a similar bill through the Senate Foreign Relations and Culture Committee. ${ }^{240}$ In October 2004, several pro-tobacco senator ${ }^{241} 242$ presented a competing bill "to create a commission to follow and control the implementation of the FCTC'243 which tobacco control advocates considered a tactic to avoid FCTC ratification. At the same time, international commercial agreements to invest in the regional tobacco industry may be used to promote a climate whereby tobacco control legislation is viewed as delaying economic progress. ${ }^{244}$

As of July 2005, Congress had not ratified the FCTC.

\section{DISCUSSION}

The tobacco industry has worked successfully for almost 40 years to block tobacco control legislation in Argentina, using similar tactics used in the USA and the rest of the world. ${ }^{12}$ The CTI was organised to provide a rapid response to new proposed legislation. As in other countries ${ }^{14}$ 47-52 the industry created a self regulation code, widely ignored, as a tool to avoid meaningful restrictions on tobacco advertising.

In the late 1970s, tobacco control advocates emerged to inform the public about smoking effects, and began to pressure public officials to restrict tobacco use. The LALCEC, a non-governmental organisation, became the leading tobacco control group in 1978, and its campaign LALCEC/83 (1978-83) was one of the most prominent examples of advocacy at that time. ${ }^{28}{ }^{32} 245-247$ In 1987, following the 6th World Conference on Smoking and Health, the UATA was formed as a coalition of institutions to advocate for a new tobacco control bill and to promote educational and prevention activities. ${ }^{247-249}$

During the 1980s, efforts to pass comprehensive tobacco control legislation intensified. However, tobacco control groups were overwhelmed by the well organised tobacco industry that prevented the passage of such bills. As of 2005, the weakened 1986 Pepe Law was the only federal legislation that established limited restrictions on tobacco advertising, and all it did was codify the industry's ineffective voluntary code. Legal restrictions on tobacco advertising are weaker than those contained in the industry's code because the industry voluntarily stopped advertising on Argentinean television in $2003^{250} 251$ in accordance with the code's 2001 version and the International Marketing Standards. No measures to regulate SHS have ever been implemented at the federal level and indoor smoking is widely prevalent.

Our findings complement earlier descriptions of the industry's "Latin Project". ${ }^{133} 134252$ Tobacco industry representatives, together with their allies, ETS consultants, 


\section{What this paper adds}

Tobacco control in Argentina is governed by a weak 1986 national law that essentially codified the tobacco industry's ineffective voluntary advertising code and a weak health warning on cigarette packages. No measures to regulate secondhand smoke have ever been taken at the federal level and indoor smoking is widely prevalent in the country.

Transnational tobacco companies have been highly influential in Argentina. Using similar strategies as elsewhere in the world, the tobacco industry successfully blocked, delayed, and diluted meaningful federal tobacco control bills. Public health officials and tobacco control advocates need to understand how the industry operates and work to isolate the industry and make it more difficult for policymakers to support the tobacco industry.

advertising agencies, and the local press, operated as an efficient and well coordinated team (similar to the Asian ${ }^{253}$ and European ${ }^{254}$ ETS consultants programmes). The veto of the Neri Bill in 1992 was the most significant success of this project and effectively deterred tobacco control legislation for over a decade. Subsequent to the Neri Bill veto, the industry and its allies proposed alternative weak bills. Even though they were not approved, these bills served to distract political and public attention so that all efforts at tobacco control legislation were neutralised.

In Argentina, as throughout the world, ${ }^{170} 183255$ the industry has also promoted its "accommodation" programme to avoid the creation of smoke-free environments and its "youth smoking prevention" programmes to show a positive image and to prevent a tobacco advertising ban and the development of meaningful tobacco control programmes. These programmes do not affect youth smoking. ${ }^{256-259}$

Strong legislation is one of the main components to curb the tobacco epidemic and associated health damage. For example, in California a large tobacco control programme financed by a tobacco tax increase, combined with smokefree workplaces and public place policies, rapidly reduced cigarette consumption and associated heart disease ${ }^{260}$ and lung cancer. ${ }^{261}$ As in Argentina, other countries in Latin America have not yet passed strong tobacco control legislation. Brazil, the single exception, has taken the lead in the region and the world. Its success relied on a strong leadership by the federal government through a National Tobacco Control Program in partnership with a broad network of tobacco control advocates, the media, and professional associations. ${ }^{262}{ }^{263}$ Federal laws have been passed ending all tobacco advertising except inside point-of-sale ${ }^{264}(2000)$, and deceptive descriptors (that is, "light" and "mild") ${ }^{265}$ (2001), and mandating strong rotating health warning labels and images on all cigarette packages ${ }^{266}$ (2003).

Public health advocates and policymakers in Argentinaand Latin America-should be aware of TTC's tactics in order to anticipate their moves. They need to develop stronger, more confrontational programmes designed to isolate the tobacco industry and to make it more difficult for politicians to support it. Not learning from others' experiences will only delay the implementation of effective tobacco control legislation in these countries.

\section{ACKNOWLEDGEMENTS}

We thank Mirta Molinari, JD with the VIGI\#A Program of the Ministry of Health in Argentina for her assistance; Dr Diego León Perazzo, President of the Argentinean Union Against Tobacco; Leonardo Daino, Director of the anti-tobacco campaign of the Argentinean League Against Cancer; and the library of the National
Congress of Argentina for the material supplied for this research. This study was funded by grants from the Tobacco Research Network Program, Fogarty International Center, National Institutes of Health (TW05935) and the National Cancer Institute (CA-87472). The funding agencies had no involvement in the conduct of the research or preparation of this paper.

\section{Authors' affiliations}

E M Sebrié*, E J Pérez-Stablet, Division of General Internal Medicine, Department of Medicine, University of California San Francisco, USA J Barnoyał, Center for Tobacco Control Research and Education, University of California San Francisco, USA

S A Glantz§, Division of Cardiology, Department of Medicine, University of California San Francisco, USA

*Also Division of Cardiology, Department of Medicine, Medical Effectiveness Research Center for Diverse Populations, Center for Tobacco Control Research and Education, University of California San Francisco

†Also Medical Effectiveness Research Center for Diverse Populations, and UCSF Comprehensive Cancer Center,

‡ Also Unidad de Cirugía Cardiovascular de Guatemala, and Medical Effectiveness Research Center for Diverse Populations

$\S$ Also Center for Tobacco Control Research and Education, and UCSF Comprehensive Cancer Center

Competing interests: none declared

\section{REFERENCES}

1 Pan American Health Organization. Health in the Americas. Washington DC: PAHO, 2002

2 MacKay J, Eriksen M, eds. The tobacco atlas. Geneva: World Health Organization, 2002.

3 Miguez H. Global Youth Tobacco Survey. Buenos Aires, Argentina: CDC/ WHO; 2000, http://www.cdc.gov/tobacco/global/gyts/factsheets/ pdf_files/argentina.pdf.

4 World Health Organization, Centers for Disease Control and Prevention Report on the results of the Global Youth Tobacco Survey in United States; 2000.http://www.cdc.gov/tobacco/global/gyts/factsheets/pdf_files/ us.pdf.

5 Shafey O, Dolwick S, Guindon G, eds. Tobacco control country profile s 2003. Atlanta, Georgia: American Cancer Society, 2003.

6 Navas-Acien A, Peruga A, Breysse P, et al. Secondhand tobacco smoke in public places in Latin America, 2002-2003. JAMA 2004;291:2741-5.

7 Philip Morris. [Table of Contents. Philip Morris International]. Feb 1980. Bates No. 2048127152/7196. http://legacy.library.ucsf.edu/tid/ edf82e00.

8 Philip Morris. [Table of Contents. Philip Morris International]. Apr 1981 Bates No. 2048120908/0962. http://legacy.library.ucsf.edu/tid/ otp92e00.

9 Philip Morris. Capital Appropriations Requisitor Manufacturing Facilities in Argentina. Nov 1980. Bates No. 2048130434/0532. http:// legacy.library.ucsf.edu/tid/nak38d00.

10 Stevens AJ. Lorillard. Closing Memorandum Imparciales - Lorillard Transaction Trademark Purchases - License Agreements Argentina Paraguay - Uruguay - Bolivia. 15 Apr 1971. Bates No. 87284221/4228. http://legacy.library.ucsf.edu/tid/vhe64c00.

11 [Tobacco International]. RJR at Home [History \& Organisational Structure]. 5 Mar 1982. Bates No. 109877629/109877649. http:// bat.library.ucsf.edu//tid/hww40a99.

12 Saloojee Y, Dagli E. Tobacco industry tactics for resisting public policy on health. Bull World Health Organ 2000;78:902-10.

13 Szilagyi T, Chapman S. Hungry for Hungary: examples of tobacco industry's expansionism. Cent Eur J Public Health 2003;11:38-43.

14 Assunta M, Chapman S. A mire of highly subjective and ineffective voluntary guidelines: tobacco industry efforts to thwart tobacco control in Malaysia. Tobacco Control 2004;13(suppl II):ii43-50.

15 Alechnowicz K, Chapman S. The Philippine tobacco industry: "the strongest tobacco lobby in Asia". Tobacco Control 2004;13(suppl II):ii71-8.

16 Assunta M, Chapman S. "The world's most hostile environment": how the tobacco industry circumvented Singapore's advertising ban. Tobacco Control 2004; 13(suppl II):ii51-7.

17 MacKenzie R, Collin J, Sriwongcharoen K, et al. "If we can just 'stall' new unfriendly legislations, the scoreboard is already in our favour" transnational tobacco companies and ingredients disclosure in Thailand Tobacco Control 2004;13(suppl II):ii79-87.

18 Chapman S, Carter SM. "Avoid health warnings on all tobacco products for just as long as we can": a history of Australian tobacco industry efforts to avoid, delay and dilute health warnings on cigarettes. Tobacco Control 2003;12(suppl III):iii13-22.

19 Hiilamo H. Tobacco industry strategy to undermine tobacco control in Finland. Tobacco Control 2003;12:414-23.

20 Gilmore A, Nolte E, McKee M, et al. Continuing influence of tobacco industry in Germany. Lancet. 2002;360: 1255; author reply 1255-6). 
21 Knight J, Chapman S. "A phony way to show sincerity, as we all well know" tobacco industry lobbying against tobacco control in Hong Kong. Tobacco Control 2004;13(suppl II):ii 13-21.

22 Sebrié E, Barnoya J, Pérez-Stable E, et al. Tobacco industry dominating national tobacco control policy making in Argentina, 1966-2005. San Francisco: University of California, San Francisco; May, 2005, http:// repositories.cdlib.org/ctcre/tcpmi/Argentina2005

23 Federal Cigarette Labeling and Advertising Act 1965

24 J Antún Resca, et al. Proposed Legislation: "Obligatoriedad de una advertencia sanitaria en todos los paquetes de cigarillos". Lower House 12 May 1966;l, 358.

25 Onganía JC, Dagnino Pastore JM. Prohibición de dar publicidad a cigarrillos. Law 18.604. Executive Branch; 6 Feb, 1970:134-135.

26 Onganía JC. Cigarrillos- Prohibición por el término de un año de la publicidad por televisión, radio y cine- Reglamentación de la ley 18.604. Decree 628. Executive Branch; 6 Feb, 1970:504-505.

27 [Hargrove GC]. Report on smoking control in places of work or in public galleries. 1970. Bates No. 301058857/301058874. http:// bat.library.ucsf.edu//tid/hhq40a99.

28 Moncalvillo M. La última "onda": aprender a no fumar. VEA 1979

29 US Public Health Service. Smoking And Health Programs Around The World. Jun 1970. Bates No. $968012023 / 2038$. http:// legacy.library.ucsf.edu/tid/cob34f00.

30 Kloepfer WJ. International Developments. 9 Mar 1970. Bates No HK0461003/1003. http://legacy.library.ucsf.edu/tid/pvc2aa00.

31 Proposed Legislation: "Obligatoriedad de una leyenda sanitaria en todo tipo de envase de tabaco" Freschi PJ. Lower House; 26 Jul 1973;Il, 1019-1020.

32 Jones RW. Self-Imposed Advertising Restrictions. 18 May 1990. Bates No. 5026031 17/502603122. http://bat.library.ucsf.edu/tid/zch30a99.

33 Proposed Legislation: "Normas sobre propaganda de cigarros y cigarillos" Frois DA. Senate; 3 Apr 1974;5, 4008-4009.

34 Holme J. Lorillard. Restrictive Advertising and Labeling Law Argentina. 1 Oct 1974. Bates No. 91007872. http://legacy.library.ucsf.edu/tid/pnr90e00.

35 Gastman MI. [Letter from M Gastman to A O'Farrell regarding a new cigarette advertising law in Argentina]. 8 Oct 1974. Bates No. 91007871 http://legacy.library.ucsf.edu/tid/onr90e00.

36 O'Farrell AD. MARVAL \& O'FARRELL. Tobacco Advertising. 14 Oct 1974 Bates No. 91007868. http://legacy.library.ucsf.edu/tid/tey54a00.

37 O'Farrell AD. MARVAL \& O'FARRELL. Translation. Oct 1974. Bates No. 91007869/7870. http://legacy.library.ucsf.edu/tid/sey54a00

38 Haines D. Lorillard. New Law on Tobacco Advertising in Argentina. 18 Sep 1974. Bates No. 91007873. http://legacy.library.ucsf.edu/tid/qnr90e00.

39 Haines D. English Version of Draft Prepared for New Cigarette Adv. Law. 5 Sep 1974. Bates No. 91007874. http://legacy.library.ucsf.edu/tid/ rnr90e00

40 Proposed Legislation: "Normas sobre propaganda de cigarros y cigarrillos Dictamen de Comisiones". Frois DA. Senate; 4 Sep, 1974:1638.

41 Cámara de la Industria del Tabaco. Philip Morris. INFOTAB Washington Workshop September 20, 1983. 20 Sep 1983. Bates No. 2501021546/ 1550. http://legacy.library.ucsf.edu/tid/pex19e00.

42 [Rubio A]. The Situation in Argentina Regarding Attempts to Restrict Publicity Nov 1980. Bates No. 502122397/2399. http://legacy.library.ucsf.edu/ $\mathrm{tid} / \mathrm{gpb} 29 \mathrm{~d} 00$

43 Jones RW. Advertising Code of Practice. 18 May 1990. Bates No. 5026031 16. http://bat.library.ucsfedu/tid/ych30a99.

44 RJ Reynolds. Argentina. Warning Label Cigarettes. Feb 1985. Bates No. 506825750/5753. http://legacy.library.ucsf.edu/tid/eyr54d00

45 Anon. Cigarette Advertising And Sampling Code Of 1964. 1964. Bates No. 947143369/3370. http://legacy.library.ucsf.edu/tid/gcr15f00.

46 Anon. Philip Morris International. Cigarette Marketing Code. 1998. Bates No. 2074188510/8547. http://legacy.library.ucsf.edu/tid/qgk45c00.

47 Chapman S. A David and Goliath story: tobacco advertising and selfregulation in Australia. BMJ 1980;281:1187-90.

48 Mindell JS. The UK voluntary agreement on tobacco advertising: a comatose policy? Tobacco Control 1993;2:209-14

49 Pollay RW. Promises, promises: self-regulation of US cigarette broadcast advertising in the 1960s. Tobacco Control 1994;3:134-44.

50 Pollay RW. Exposure of US youth to cigarette television advertising in the 1960s. Tobacco Control 1994:3:130-3.

51 Richards J Jr, Tye J, Fischer P. The tobacco industry's code of advertising in the United States: myth and reality. Tobacco Control 1996;5:295-311

52 Barbeau EM, DeJong W, Brugge DM, et al. Does cigarette print advertising adhere to the Tobacco Institute's voluntary advertising and promotion code? An assessment. J Public Health Policy 1998;19:473-88.

53 American Tobacco. Guidelines, The Role Of ICOSI. 13 Apr 1978. Bates No. 980037036/7037. http://legacy. library.ucsf.edu/tid/vkq90c00.

54 Anon. The Role of INFOTAB. 20 Nov 1981. Bates No. 2501029902/9918. http://legacy.library.ucsf.edu/tid/blp39e00.

55 Walther C. Reemtsma Cigarettenfabriken. [Letter regarding summary of meeting in Denham]. 17 Sep 1991. Bates No. $301124309 / 301124311$. http://bat.library.ucsf.edu//tid/wxh00a99.

56 Anon. ICOSI/NMA Workshop Meeting Frankfurt November 11-13 1980. 30 Oct 1980. Bates No. 502122343/2344. http://legacy.library.ucsf.edu/ tid/ihi6lc00.

57 Anon. ICOSI/NMA Workshop Meeting. 11-13 November, 1980Frankfurt, Germany. General Theme: "Issues Know No Frontiers", 13 Nov 1980.Bates No.502122393/2396.http://legacy.library.ucsf.edu/tid/ fpb29d00.

58 Philip Morris International. Philip Morris. Corporate Affairs Status Report. 1981. Bates No. 2025881685/1708. http://legacy.library.ucsf.edu/tid/ djd81f00.
59 Rubio A. INFOTAB Workshop for NMA Washington, D.C. Argentina Information Seminars. Sep 1983. Bates No. 2501021551/1563. http:// legacy.library.ucsf.edu/tid/qex19e00.

60 INFOTAB. NMA Workshop Washington. September 19-22, 1983. 19 Sep 1983. Bates No. 2501021486/1489. http://legacy.library.ucsf.edu/tid/ zex19e00.

61 INFOTAB. Latin America. Visit to Uruguay, Argentina and Brazil May 30June 4. 4 Jun 1983. Bates No. 690156537/6541. http:// legacy.library.ucsf.edu/tid/oqo93f00.

62 Seligman RB. Philip Morris, Tobacco Technology Group. South American Trip (Argentina, Brazil, and Venezuela) January 20-February 3, 1984. 9 Feb 1984. Bates No. 2000510174/0187. http://legacy.library.ucsf.edu/ $\mathrm{tid} / \mathrm{kkw} 56 \mathrm{e} 00$

63 INFOTAB. Cámara de la Industria del Tabaco. Impacto Económico (Economic Impact). 26 Jun 1984. Bates No. 690155005/5007. http:// legacy.library.ucsf.edu/tid/qgl02d00.

64 Giambroni A. Cámara de la Industria del Tabaco. [Copies of Booklet on Economic Impact of Argentine Tobacco Industry]. 4 Apr 1984. Bates No. TI09930614. DOJ CIVIL. http://legacy.library.ucsf.edu/tid/rza40c00.

65 Cámara de la Industria del Tabaco. Impacto Económico [Economic Impact]. 1984. Bates No. TI09930615/0616. DOJ CIVIL. hHtp:// legacy.library.ucsf.edu/tid/qza40c00.

66 Publicidad de cigarrillos- Pautas. Ruling 422. Campero R. Secretaría de Comercio; 23 May, 1984.

67 Anon. INFOBRIEF Issues and Trends Vol.2 No.3 [Recent Tobacco Advertising and Promotion Restrictions]. Jul 1985. Bates No. 10415237/5241. http:// legacy.library.ucsf.edu/tid/esq4aa00.

68 Anon. Tobacco Alert Vol. 1, No. 1. Mar 1984. Bates No. 10416613/6618. http://legacy.library.ucsf.edu/tid/jqr4aa00.

69 Proposed Legislation:"Régimen regulador de la publicidad, venta, distribución y consumo de tabaco, cigarros y cigarrillos, y de las actividades relacionadas con el hábito de fumar y sus consecuencias dañosas para la salud" Maglietti AR. Lower House; June, 1984.

70 Corti A. A. Corti Report on Visits to Brazil, Argentina, Venezuela, Mexico (November 22- December 7). 7 Dec 1984. Bates No. 2023272522/2526. http://legacy.library.ucsf.edu/tid/szu71fo0.

71 INFOTAB. Second Latin American Workshop; Doral Hotel and Country Club; Miami, U.S.A.; July 29-31, 1985. 29 Jul 1985. Bates No. TIMN0289347/ 9600. Minnesota AG. http://legacy.library.ucsf.edu/tid/jpr62f00.

72 Tobacco Documentation Center. [Bill for Smoking Control Act]. 8 May 1994. Bates No. 500826925. http://bat.library.ucsf.edu/tid/qgb30a99.

73 Tobacco Institute. Tobacco Institute Newsletter Number 393. 29 Oct 1985 Bates No. 950309124/9129. http://legacy.library.ucsf.edu/tid/cxi34f00.

74 Bunoski A. Tobacco Institute Newsletter. 1 Oct 1985. Bates No. 505482252/2258. http://legacy.library.ucsf.edu/tid/ymr15d00

75 Bonasegna C. Argentina's tobacco ads might be banned. Advertising Age 14 Oct, 1985; Sec.International p.56.

76 Philip Morris. Country News in Brief. Nov 1985. Bates No. $2501109730 /$ 9731. http://legacy.library.ucsf.edu/tid/bxq22e00.

77 Philip Morris. Country News in Brief. 4 May 1986. Bates No. $2501109742 /$ 9743. http://legacy.library.ucsf.edu/tid/gcu39e00.

78 Philip Morris. Country News in Brief. I Feb 1986. Bates No. $2501109737 /$ 9739. http://legacy.library.ucsf.edu/tid/exq22e00.

79 Brailovsky AE, ed. El negocio de envenenar. Buenos Aires: Editorial Fraterna, 1988

80 Ely R. Discussions with Jorge Basso Dastugue, Millbank, 22 February 1986. 24 Feb 1986. Bates No. 503133475/503133478. http:// bat.library.ucsf.edu/tid/zki40a99.

81 Gilderdale R. [Telefax from RF Gilderdale to JJ Mostyn regarding the Kattan lawsuit against the COMFER]. 1986. Bates No. 503133473/503133474. http://bat.library.ucsf.edu/tid/yki40a99.

82 Restricciones en la publicidad de tabacos, cigarrillos, cigarros $u$ otros productos destinados a fumar- Leyenda que deberán llevar los envases Law 23.344. Pepe LA. Lower House; 21 Aug, 1986.

83 Proposed Legislation: "Limitaciones para la publicidad de tabacos, cigarros, cigarrillos u otros objetos destinados a fumar y sus envases" Pepe LA. Lower House; March, 1984

84 Adlkofer F, Alford P, Corner R, et al. Tobacco Institute. INFOTAB International Workshop Brussels Hilton Hotel Brussels Belgium. October 1316, 1986. 16 Oct 1986. Bates No. 2501446636/7080. http:// legacy.library.ucsf.edu/tid/alrO2a00.

85 CLACCTA. Jul-Aug-Sep, 1989 Report No. 8.

86 Anon. Philip Morris. Antismoking Legislation in Argentina. 1991. Bates No. 2503002518. http://legacy.library.ucsf.edu/tid/cwp19e00

87 Anon. Philip Morris. [Labor Pathology Congress- World Antismoking Conference- Antismoking Legislation- Neri's Antismoking Bill]. 1991. Bate No. 2503002520/2524. http://legacy.library.ucsf.edu/tid/ewp19e00.

88 Proposed Legislation: "Ley de Control del Tabaquismo" Law 24.152. Neri AC. Lower House; 27 Sep, 1990

89 Rodriguez C. Philip Morris. Veto of Anti Tobacco Law Case Analysis: Argentina, 1992.Bates No.2046436807/6872.http:// legacy.library.ucsf.edu/tid/qoa65e00.

90 Nobleza-Piccardo. [Public Affairs Review 1993 Latin America \& CaribbeanArgentina]. 1992. Bates No. 500830568/500830588. http:// bat.library.ucsf.edu//tid/yeg00a99.

91 Anon. Philip Morris. Neri's Antismoking Bill. 1991. Bates No. 2503002519. http://legacy.library.ucsf.edu/tid/dwp19e00

92 World Health Organization. Tobacco company strategies to undermine tobacco control activities at the World Health Organization. Geneva: WHO, 2000 
93 Muggli ME, Hurt RD. Tobacco industry strategies to undermine the 8th World Conference on Tobacco or Health. Tobacco Control 2003;12:195-202.

94 Anon. Anti-Smoking Conference, Buenos Aires. 25 Feb 1992. Bates No. 2503002514/2515. http://legacy.library.ucsf.edu/tid/sma42e00.

95 Rodriguez C. Philip Morris International. Actions in Preparation of the 8th World Conference. 3 Mar 1992. Bates No. 250300251 1/2513. http:// legacy.library.ucsf.edu/tid/rma42e00.

96 Anon. Buenos Aires Conference- March 30/ April 3, 1992, Work Project. 1992. February Bates No. 300504231/300504263. http:// www. library.ucsf.edu/tobacco/batco/html/14400/14453/index.html

97 Anon. 8th World Conference on Tobacco or Health. Building A TobaccoFree World, March 30- April 3, 1992, Buenos Aires, Argentina. 30 Mar 1992. Bates No. 950186691/6699. http://legacy.library.ucsf.edu/tid/ hzd54f00.

98 Anon. 8th World Conference on Tobacco or Health: Building a Tobacco-Free World Sheraton Hotel Buenos Aires, Argentina Dates: March 30-April 3. 4 Mar 1992. Bates No. 2025807764/7774. http://legacy.library.ucsf.edu/ $\mathrm{tid} /$ isn $14 \mathrm{e} 00$.

99 Anon. Philip Morris. Monitors Notes. 1992. Bates No. 2500121044. http:// legacy.library.ucsf.edu/tid/mxk19e00.

100 Anon. Philip Morris. Personalities and Organisation - 8th WCTH. 1992 Bates No. 2500121045/1048. http://legacy.library.ucsf.edu/tid/ nxk19e00.

101 Anon. Philip Morris. Auspicios Internacionales International Sponsors. 1992 Bates No. 2500121049/1050. http://legacy.library.ucsf.edu/tid/ ece42e00

102 Anon. Philip Morris. Schedule of Keynote Speakers. 1992. Bates No. 2500121051. http://legacy.library.ucsf.edu/tid/fce42e00.

103 Anon. Philip Morris. List of Leading Activists. 1992. Bates No. 2500121052/1053. http://legacy.library.ucsf.edu/tid/gce42e00.

104 Anon. Philip Morris. [List of Participants to the 8th World Conference on Tobacco or Health]. 1992. Bates No. 2500121054/1058. http:// legacy.library.ucsf.edu/tid/hce42e00.

105 Gonzalez A. Philip Morris International. 8th World Conference. 25 Mar 1992. Bates No. 2503002479. http://legacy.library.ucsf.edu/tid/ kwpl9e00.

106 Gonzalez AM. Philip Morris International. Monitoring 8th World Conference - Buenos Aires. 25 Mar 1992. Bates No. 2503002480/2481. http:// legacy.library.ucsf.edu/tid/owp19e00.

107 Gonzalez AM. Philip Morris International. 8th World Conference. 20 Mar 1992. Bates No. 2503002482. http://legacy.library.ucsf.edu/tid/ Ima42e00.

108 Vives J. Octava Conferencia. 19 Mar 1992. Bates No. 2503002483. http://legacy.library.ucsf.edu/tid/mma42e00.

109 Anon. Philip Morris. Posters. Tuesday March 31. 31 Mar 1992. Bates No. 2503002484/2487. http://legacy.library.ucsf.edu/tid/nma42e00.

110 Anon. Philip Morris. Posters. Wednesday April 1. 19 Mar 1992. Bates No. 2503002488/2491. http://legacy.library.ucsf.edu/tid/oma42e00.

111 Anon. Posters. Thursday April 2. 19 Mar 1992. Bates No. 2503002492/ 2495. http://legacy.library.ucsf.edu/tid/gwp19e00

112 Anon. Philip Morris. Videos. Thursday April 2. 19 Mar 1992. Bates No. 2503002496/2497. http://legacy.library.ucsf.edu/tid/hwp19e00.

113 Boyse S. BATCo Millbank. Visit to Argentina, 29-30 July 1991 and Update on Activities in South America. 8 Aug 1991. Bates No. 304004032/ 304004034. http://www.library.ucsf.edu/tobacco/batco/bin/ showalldata.cgi?page $=. . / \mathrm{html} / 14900 / 14967 /$ index. $\mathrm{html}$.

114 Bugna M. 8th World Conference on Tobacco or Health. 23 Oct 1991. Bates No. 2023545716/5720. http://legacy.library.ucsf.edu/tid/rav78e00.

115 Unión Antitabáquica Argentina. 8a Conferencia Mundial Sobre Tabaco O Salud. Oct 1991. Bates No. 2023545721. http://legacy.library.ucsf.edu/ $\mathrm{tid} / \mathrm{sav} 78 \mathrm{e} 00$

116 Basso Dastugue JR. 8th World Conference on Smoking \& Health [Letter from J.R. Basso Dastugue to S. Boyse]. 14 Jun 1991. Bates No. 304004077/ 304004078. http://www.library.ucsf.edu/tobacco/batco/html/14900/ $14969 /$ index.html.

117 Anon. 8th International Conference on Tobacco and Health. Proposed possible action to take against it. 1991. Bates No. 300504152/ 300504157. http://www.library.ucsf.edu/tobacco/batco/html/14400/ 14451/index.html.

118 Dietrich P. [Letter from Paul Dietrich to Aurora Gonzales regarding Proposed Argentina Project for Children's Vacination]. 6 Sep 1991. Bates No. 300516109/300516111. http://www.library.ucsf.edu/tobacco/batco/ $\mathrm{html} / 14400 / 14482 /$ index.html.

119 Gonzalez AM. Philip Morris International. 8th Anti-Smoking World Conference. 9 Aug 1991. Bates No. 2503002530/2531. http:// legacy.library.ucsf.edu/tid/zvp19e00.

120 May R. Philip Morris. World Conference on Smoking and Health. 13 May 1991. Bates No. 2028463229. http://legacy.library.ucsf.edu/tid/ sco56e00.

121 Anon. Unión Antitabáquica Argentina. Invitation. 19-24 April, 1992 Buenos Aires, Argentina. 8th World Conference on Smoking and Health. 1991. Bates No. 2028463230/3231. http://legacy.library.ucsf.edu/tid/ tco56e00.

122 Anon. Philip Morris. VIII World Conference on Tobacco or Health. 1991. Bates No. 2503002517. http://legacy.library.ucsf.edu/tid/bwp19e00.

123 Anon. La historia de una coima. Call Money 15 Oct, 1992.

124 Anon. Britos nego haber cobrado una coima. El Cronista 16 Oct, 1992

125 Anon. Ley antitabaco. Britos: "No pedí coima", Página 1216 Oct, 1992

126 Anon. Britos negó una grave acusación en su contra. La Nación 16 Oct, 1992;Sec.Economía.
127 Romero Feris JA. La ley contra el tabaquismo es anticonstitucional. El Cronista 4 Oct, 1992; Sec. Opinión, 13.

128 Anon. Disparidad oficial de criterios sobre la norma antitabáquica. Romero Feris fundamentó su oposición. La Nación 2 Oct, 1992:Sec. Ciudad, 19.

129 Paredes EJ. Temen efectos económicos por la ley antitabaco. El Cronista, 1992; Sec.Política, 5.

130 Anon. Golpe al cigarrillo. Publicidad prohibida. El Cronista 1 Oct, 1992.

131 Anon. Polémica por la sanción de las restricciones para fumar. Varios sectores se preparan para lanzar una campaña contra la ley antitabaco. Clarín 6 Oct, 1992;Sec. Información General, 34-35.

132 Anon. Desacuerdo con la regulación de la publicidad sobre cigarrillos. La Nación 11 Oct, 1992.

133 Barnoya J, Glantz S. Tobacco industry success in preventing regulation of secondhand smoke in Latin America: the "Latin Project". Tobacco Control 2002;11:305-14.

134 Aguinaga Bialous S, Shatenstein S. Profits over People: Tobacco Industry Activities to Market Cigarettes and Undermine Public Health in Latin America and the Caribbean: PAHO; 2002. http://www.paho.org/English/HPP/ $\mathrm{HPM} / \mathrm{TOH} /$ profits_over_people.pdf.

135 Alvarez CB. Instituto de las Clínicas Cardiovasculares. [Letter from CB Alvares to J Rupp regarding the scientific arguments of the relation between ETS and diseases]. 12 Nov 1992. Bates No. 300543203. http:// bat.library.ucsf.edu//tid/yoi00a99.

136 Davies PS. Covington \& Burling. [Letter from P Davies to J Basso Dastugue and J Vives regarding CB Alvarez' fees]. 3 Dec 1992. Bates No. 300543199. http://bat.library.ucsf.edu//tid/uoi00a99.

137 Rupp JP. Covington \& Burling. [Letter from J Rupp to J Basso Dastugue and J Vives regarding the ETS Consultancy Program in Argentina]. 23 Nov 1992. Bates No. 2023591387/1389. http://legacy.library.ucsf.edu/tid/ kwf46e00

138 Rupp JP. Covington \& Burling. Meetings in Buenos Aires Relating to the ETS Consultants Program. 13 Nov 1992. Bates No. 250301 1668/1677. http:// legacy.library.ucsf.edu/tid/zmk02a00.

139 Ruiz Nuñez H. Por qué se vetó la ley antitabaco. La conexión MenemCaserta-Philip Morris. HUMOR, 1992 Oct.

140 Proposed Legislation:" Programa Nacional Permanente de Prevención y Lucha contra el Tabaquismo" Molina PE. Senate; 3 Nov, 1992.

141 Massalin-Particulares. National Anti Tobacco and Prevention Program (Molina Law). 1 Nov 1997. Bates No. 2065326489/6501. http:// legacy.library.ucsf.edu/tid/kuo63c00.

142 Segura D, Basso Dastugue JR. Anti-Tobacco Litigation. 10 May 1995. Bates No. 503133426/503133429. http://bat.library.ucsf.edu//tid/ awe80a99.

143 Pepe LA, Corchuelo Blasco JM. Proposed Legislation: "Obligatoriedad de consignar en los envases comerciales de productos destinados a fumar, su contenido en nicotina y alquitran" ${ }^{\prime \prime}$ Lower House; Aug, 1995.

144 Gonzalez AM. Philip Morris. Argentina. 3 Oct 1996. Bates No. 2061682612. http://legacy.library.ucsf.edu/tid/cto67d00.

145 Vives J. Philip Morris Latin America. [Letter from J Vives to A Gonzalez regarding Nobleza-Piccardo's Press Conference on "Regulatory Framework of Tobacco in Argentina"]. 3 Oct 1996. Bates No. 2061682613. http:// legacy.library.ucsf.edu/tid/dto67d00.

146 Basso Dastugue J. Nobleza-Piccardo. Nobleza-Piccardo Incluye los Contenidos de Nicotina y Alquitran en sus Marquillas. 3 Oct 1996. Bates No. 2061682614/2615. http://legacy library.ucsf.edu/tid/eto67d00.

147 Leiber C. Philip Morris International. Facsimile Cover Sheet. 4 Oct 1997. Bates No. 2065329162. http://legacy.library.ucsf.edu/tid/ugp63c00.

148 Vives J. Philip Morris Latin America. [Letter from J Vives to A Gonzalez regarding Nobleza-Piccardo's Press Conference on "Regulatory Framework of Tobacco in Argentina"]. 3 Oct 1996. Bates No. 2065329163. http:// legacy.library.ucsf.edu/tid/xfp63c00.

149 Basso Dastugue J. Nobleza-Piccardo. Simultaneously with the Launching of Kent Super Lights Nobleza-Piccardo Includes Nicotine and Tar Contents on Labels. 3 Oct 1996. Bates No. 2065329164/9165. http:// legacy.library.ucsf.edu/tid/yfp63c00.

150 Basso Dastugue J. Nobleza-Piccardo. Nobleza-Piccardo to Include Content of Nicotine and Tar in lts Brands. 3 Oct 1996. Bates No. 2065329166/ 9168. http://legacy.library.ucsf.edu/tid/zfp63c00.

151 Leiber C. Philip Morris International. Facsimile Cover Sheet. 4 Oct 1996. Bates No. 2065329186. http://legacy.library.ucsf.edu/tid/hgp63c00.

152 Vives J. Philip Morris International. [Memorandum from J Vives to A Gonzalez regarding Nobleza-Piccardo's decision to disclose tar and nicotine content on cigarette packs]. 4 Oct 1996. Bates No. 2065329187/ 9188. http://legacy.library.ucsf.edu/tid/igp63c00.

153 Anon. Philip Morris International. Los Cigarrillos Indicarán Contenidos de Nicotina y Alquitrán. 3 Oct 1996. Bates No. 2065329189. http:// legacy.library.ucsf.edu/tid/igp63c00.

154 Anon. Clarín. Paquetes de Cigarillos. 4 Oct 1996. Bates No. 2065329190. http://legacy.library.ucsf.edu/tid/hfp63c00 (Accessed 25 April 2005).

155 Anon. La Prensa. Las Tabacaleras Brindarán Información sobre Toxinas. 4 Oct 1996. Bates No. 2065329191. http://legacy.library.ucsf.edu/tid/ ifp63c00.

156 Anon. Ambito Financiero. Novedosa Medida en Cigarillos. 4 Oct 1996. Bates No. 2065329192. http://legacy.library.ucsf.edu/tid/ifp63c00.

157 Anon. La Nación. Informan sobre Nicotina en Atados de Cigarrillos. 4 Oct 1996. Bates No. 2065329193. http://legacy.library.ucsf.edu/tid/ kfp63c00.

158 Anon. Diario Popular. Puchos para Pensar. 4 Oct 1996. Bates No. 2065329194. http://legacy.library.ucsf.edu/tid/Ifp63c00.

159 Anon. Página 12. No Todo es Tabaco en un Cigarillo. 4 Oct 1996. Bates No. 2065329195. http://legacy.library.ucsf.edu/tid/mfp63c00. 
160 Anon. Cuarto Poder. Cigarrillos: Imprimirán Niveles de Nicotina, 4 Oct 1996.Bates No.2065329196.http://legacy.library.ucsf.edu/tid/nfp63c00

161 Anon. Buenos Aires Herald. Nobleza Leapfrogs Congress. 4 Oct 1996. Bates No. 2065329197. http://legacy.library.ucsf.edu/tid/ofp63c00.

162 Anon. El Economista. Nobleza ahora compite en información. 4 Oct 1996. Bates No. 2065329198. http://legacy.library.ucsf.edu/tid/pfp63c00.

163 Anon. El Cronista. Nobleza-Piccardo se Anticipó a la Norma. 4 Oct 1996. Bates No. 2065329199. http://legacy.library.ucsf.edu/tid/fkt83c00

164 Otálora E. Interview with Ernesto M Sebrié. In:Buenos Aires, Argentina. 2003.

165 Proposed Legislation: "Reproducción del proyecto de ley sobre creación del programa nacional permanente de prevención y lucha contra el tabaquismo" Ulloa RA. Senate; 12 May, 1998.

166 Proposed Legislation:"Proyecto de ley sobre la creación del programa nacional permanente de prevención y lucha contra el tabaquismo" Mazza AJ. Senate; Oct, 1998

167 Sainz C. Philip Morris. For Your Information. 1998. Bates No. 2072522324A. http://legacy.library.ucsf.edu/tid/udb06c00

168 Mazza A. Bertrand Languages. Argentina Republic National Senate. 1998 Bates No. 2072522325/2337. http://legacy.library.ucsf.edu/tid/ $\mathrm{vdb06} \mathrm{c00}$.

169 Samuels BE, Begay ME, Hazan AR, et al. Philip Morris's failed experiment in Pittsburgh. J Health Polit Policy Law 1992;17:329-51

170 Dearlove JV, Bialous SA, Glantz SA. Tobacco industry manipulation of the hospitality industry to maintain smoking in public places. Tobacco Control 2002;11:94-104.

171 Nobleza-Piccardo. Reporte Social 2001-2002, Buenos Aires; 2002.http:// www.noblezapiccardo.com/oneweb/sites/NOB_58LMXM.nsf / vwPagesWeblive/ 476356E94317D0A180256C0500654DEEopendocument\&SID = 6ADDAEC69CD10AA463E10F23AE7B93DC\&DTC $=20050426$ (Accessed 25 April 2005).

172 Nobleza-Piccardo. Balance Social. Newsletter No.2, Buenos Aires; Dec, 2002.http://www.noblezapiccardo.com/oneweb/sites/NOB_58LMXM.nsf /vwPagesWeblive/

A83BB99C6FBD781E80256C950047E443opendocument\&SID = 6ADDAEC69CD10AA463E10F23AE7B93DC\&DTC $=20050426$ (Accessed 25 April 2005).

173 Leiber CL. Philip Morris International. Latin America Report: Youth Access Prevention and Education Programs, 28 Aug 1997.Bates No.2074188891/ 8892.http://legacy.library.ucsf.edu/tid/ajk45c00.

174 [Leiber C. ]. Philip Morris Latin America. Youth Access Prevention and Education Programs. Aug 1997. Bates No. 2074188893. http:// legacy.library.ucsf.edu/tid/bjk45c00.

175 Leiber CL. Philip Morris International. Latin America Youth Access Prevention and Education Programs. 28 Aug 1997. Bates No. 2074188894. http:// legacy.library.ucsf.edu/tid/cjk45c00.

176 [Leiber C. ]. Philip Morris Latin America. [Latin America Youth Access Prevention and Education Programs]. Aug 1997. Bates No. 2074188895. http://legacy.library.ucsf.edu/tid/djk45c00.

177 [Leiber C. ]. Philip Morris International. Cigarette Marketing Code. 17 Apr 1997. Bates No. 2074188896/8925. http://legacy.library.ucsf.edu/tid/ ejk45c00.

178 Leiber CL. Philip Morris International. Latin America Youth Access Prevention \& Education Initiatives. 1 Oct 1998. Bates No. 2074188506/8507. http:// legacy.library.ucsf.edu/tid/ogk45c00.

179 Leiber CL. Philip Morris Latin America. Youth Access Prevention and Education Initiatives. Sep 1998. Bates No. 2074188508/8509. http:// legacy.library.ucsf.edu/tid/pgk45c00.

180 Anon. Philip Morris International. [1998 Youth Smoking Prevention Initiatives. A Review of Programs]. 1998. Bates No. 2072128521/8550. http://legacy.library.ucsf.edu/tid/esj27d00.

181 Bible GC. Philip Morris Latin America. Youth Smoking Prevention 1999 2000. 1999. Bates No. 2080005047/5086. http:// legacy.library.ucsf.edu/tid/ktq80c00.

182 [Hendrys PW]. Philip Morris International. Global Youth Smoking Prevention Programs. 2000. Bates No. 325128344/325128361. http:// bat.library.ucsf.edu//tid/pqi6la99.

183 Landman A, Ling PM, Glantz SA. Tobacco industry youth smoking prevention programs: protecting the industry and hurting tobacco control. Am J Public Health 2002;92:917-30.

184 Leiber CL. Philip Morris Latin America. Yo Tengo Poder. Jun 1998. Bates No. 2069582763/2767. http://legacy.library.ucsf.edu/tid/rqw32d00.

185 Anon. Philip Morris. Advertising Code Comparison. May 1993. Bates No. 250011 4689/4696. http://legacy.library.ucsf.edu/tid/uhd42e00.

186 Gembler A. PMI Guidelines for Approaching Tobacco Regulatory Issues. Jan 1998. Bates No. 2072522354/2356. http://legacy.library.ucsf.edu/tid/ eeb06c00.

187 British American Tobacco. Cigarette Advertising and Promotion Code of Practice. Nov 1996. Bates No. 2072664716/4717. http:// legacy.library.ucsf.edu/tid/ltg42c00.

188 Sainz HC. Philip Morris. The Marketing Code of the Chamber of Tobacco in Argentina. 6 Nov 1997. Bates No. 2072522372/2373. http:// legacy.library.ucsf.edu/tid/jeb06c00.

189 Sainz HC. Philip Morris. [Memorandum from C Sainz regarding the Argentinean industry marketing code]. 6 Nov 1997. Bates No. 2072522371. http://legacy.library.ucsf.edu/tid/ieb06c00.

190 Tilley K. Philip Morris. [Memorandum from K Tilley to C Sainz regarding the Argentinean industry marketing code]. 30 Oct 1997. Bates No. 2072554669. http://legacy.library.ucsf.edu/tid/cqd42c00.
191 Tilley K. Cámara de la Industria del Tabaco. Código para la promoción, venta y publicidad de cigarrillos. 30 Oct 1997. Bates No. 2072554671/ 4672. http://legacy.library.ucsf.edu/tid/bqd42c00.

192 Sainz HC. Philip Morris. [Memorandum from C Sainz regarding the Argentinean industry marketing code]. $6 \mathrm{Nov}$ 1997. Bates No. 2072554674. http://legacy.library.ucsf.edu/tid/aqd42c00.

193 Sainz HC. Philip Morris. [Memorandum from C Sainz regarding the Argentinean industry marketing code]. 6 Nov 1997. Bates No. 2072554663. http://legacy.library.ucsf.edu/tid/dqd42c00.

194 Cámara de la Industria del Tabaco. Código para Promoción, Venta y Publicidad de Productos del Tabaco; 2001. http:// www.noblezapiccardo.com/oneweb/sites/NOB_58LMXM.nsf / vwPagesWeblive/

80256B88005D664880256B87005E447Fopendocument\&SID = E73D03887F82EC6337E49F3CB31A77A2\&DTC $=20050105$ (Accessed Nov 2004).

195 BAT, Japan Tobacco, PMI. Estándares Internacionales para la Comercialización y Publicidad de Productos de Tabaco; 2001. http:// www.noblezapiccardo.com/oneweb/sites/NOB_58LMXM.nsf / vwPagesWebLive/

625E85A085D236CB48256BA700547B77opendocument\&SID = E73D03887F82EC6337E49F3CB31A77A2\&DTC $=20050105$ (Accessed 20 Feb 2005)

196 Proposed Legislation: "Régimen nacional de regulación de la fabricación, comercialización, publicidad, y consumo de productos que contengan tabaco" Garré NC. Lower House; Jun, 1998.

197 Costa S. Smoking Restrictions. 24 Jun 1998. Bates No. 2072554880 http://legacy.library.ucsf.edu/tid/xbe42c00.

198 Sainz C. Philip Morris. For Your Information. Jan 1998. Bates No. 2072522357. http://legacy.library.ucsf.edu/tid/feb06c00.

199 Sainz C. Bertrand Languages. Bill. National Law Regulating the Manufacturing, Marketing, Advertising, and Consumption of Products Containing Tobacco. Jun 29 1998. Bates No. 2072522358/2368. http:// legacy.library.ucsf.edu/tid/geb06c00.

200 Sainz C. Philip Morris. Argentina Tobacco Bill. 7 Jul 1998. Bates No. 2072522352. http://legacy.library.ucsf.edu/tid/ceb06c00.

201 Gembler A. Philip Morris International. Guidelines on Public Policy Issues. 12 Jan 1998. Bates No. 2072522353. http://legacy.library.ucsf.edu/tid/ deb06c00.

202 Sainz C. Philip Morris. [Memorandum from C Sainz regarding the draft for Argentina]. $10 \mathrm{Jul}$ 1998. Bates No. 2072522338. http:// legacy.library.ucsf.edu/tid/wdb06c00

203 Sainz C. Philip Morris. Argentine Tobacco Control Bill. 10 Jul 1998. Bates No. 2072522339/2343. http://legacy.library.ucsf.edu/tid/xdb06c00.

204 Drope J, Bialous SA, Glantz SA. Tobacco industry efforts to present ventilation as an alternative to smoke-free environments in North America. Tobacco Control 2004;13(suppl I):i41-7.

205 Federal Cigarette Labeling and Advertising Act 15 U.S.C. §1335a. 1984

206 Esteves LG, Madrigal M. Informacion WRA. 21 Jul 1998. Bates No. 2072554838. http://legacy.library.ucsf.edu/tid/ybe42c00.

207 Sainz C. Philip Morris. [Memorandum from C Sainz to L G Esteves regarding Act 15 U.S.C. §1335a]. 23 Jul 1998. Bates No. 2072522348. http:// legacy.library.ucsf.edu/tid/aeb06c00.

208 Sainz C. List of Cigarette Ingredients, Annual Submission to Secretary Transmittal to Congress, Confidentiality. Jul 1998. Bates No. 2072522349/ 2351. http://legacy.library.ucsf.edu/tid/beb06c00.

209 Sainz C. Philip Morris. Argentina Tobacco Bill. 5 Aug 1998. Bates No. 2072522344. http://legacy.library.ucsf.edu/tid/ydb06c00.

210 Liebengood H. [Attachment to March 13, 1998 letter from $\mathrm{H}$ Liebengood to Chairman T Bliley]. 13 Mar 1998. Bates No. 2072522345/2347. http:// legacy.library.ucsf.edu/tid/zdb06c00

211 Neri AC. Proposed Legislation: "Régimen de Control del Tabaquismo". Lower House; 26 Sep 2002. http://wwwl.hcdn.gov.ar/dependencias/ dsecretaria/ Periodo2002/PDF2002/TP2002/07setiembre2002/ tp144/ 6185-D-02pdf (Accessed 25 April 2005).

212 Picazo SA. Proposed Legislation: "Prohibición de fumar en oficinas del Estado". Lower House; 1 Mar, 2002.

213 Polino HT. Proposed Legislation:"Régimen para la restricción del consumo del tabaco y su publicidad. Programa nacional contra el tabaco". Lower House; 15 Mar, 2002.

214 Monteagudo ML. Proposed Legislation:"Régimen de defensa de las personas no fumadoras". Lower House; 19 Mar, 2002.

215 Parentella IF, et al. Proposed Legislation:"Régimen nacional de lucha contra el tabaquismo". Lower House; 16 May 2002. http://www1.hcdn.gov.ar/ dependencias/dsecretaria/Periodo2002/ PDF2002/TP2002/ 03mayo2002/ Tp052/2430-D-02pdf (Accessed 25 April 2005).

216 Osorio ML. Proposed Legislation:" Modificación del Art. 1 de la ley 23.344, régimen que propicia la inclusión de una leyenda en los envases de comercialización de tabaco". Lower House; 31 May 2002. http:// wwwl .hcdn.gov.ar/dependencias/dsecretaria/ Periodo2002/PDF2002/ TP2002/03mayo2002/ Tp062/2956-D-02pdf (Accessed 25 April 2005).

217 Narducci A, et al. Proposed Legislation:"Modificación del Art. 1 de la ley 23. 344 de envases de los cigarrillos, sobre la inclusión de una leyenda: El fumar es perjudicial para la salud", Lower House; 15 Nov 2002.http:// wwwl.hcdn.gov.ar/dependencias/dsecretaria/ Periodo2002/PDF2002/ TP2002/09noviembre2002/ tp179/7334-D-02pdf (Accessed 25 April 2005).

218 Pepe LA. Proposed Legislation:" Prohibición de fumar en ambientes donde se expenden y/o consumen comestibles". Lower House; 18 Nov 2002. http:// wwwl.hcdn.gov.ar/dependencias/dsecretaria/ Periodo2002/PDF2002/ 
TP2002/09noviembre2002/ tp180/7356-D-02pdf (Accessed 25 April 2005).

219 Chaya ML. Proposed Legislation:"Modificación del Art. 1 de la ley 23.344 sobre el espacio de la leyenda 'El fumar es periudicial para la salud', en los envases de los productos destinados al fumador". Lower House; 3 Mar 2003. http://wwwl .hodn. gov.ar/dependencias/dsecretaria/ Periodo2003/PDF2003/TP2003/01 marzo2003/ tp001/0060-D-03pdf (Accessed 25 April 2005).

220 Bortolozzi de Bogado AR. Proposed Legislation:"Prohibición de toda forma directa o indirecta de publicidad, promoción o patrocinio de tabaco y sus derivados destinados a fumar". Lower House; 3 Mar 2003. http:// wwwl.hcdn.gov.ar/dependencias/dsecretaria/ Periodo2003/PDF2003/ TP2003/01 marzo2003/ tp001/0149-D-03pdf (Accessed 25 April 2005)

221 Correa JC. Proposed Legislation:"Régimen para la prohibición de fumar en lugares cerrados y de atención al público en dependecias oficiales". Lower House; 4 Mar 2003. http://wwwl .hcdn.gov.ar/dependencias/ dsecretaria/Periodo2003/PDF2003/TP2003/01 marzo2003/ tp002/ 0206-D-03pdf (Accessed 25 April 2005).

222 Vázquez RH, Stolbizer MR. Proposed Legislation:"Modificaciones de la ley 23.344. Régimen por el cual se procura la inclusión de la leyenda en los envases de comercialización de tabaco que advierte sobre su toxocidad y se limita la propaganda para su consume". Lower House; 14 Mar 2003. http://wwwl .hcdn.gov.ar/dependencias/dsecretaria/ Periodo2003/ PDF2003/TP2003/01 marzo2003/ tp010/0595-D-03pdf (Accessed 25 April 2005).

223 Roy I, et al. Proposed Legislation:"Régimen nacional de lucha contra el tabaquismo". Lower House; 18 Mar 2003. http://wwwl.hcdn.gov.ar/ dependencias/dsecretaria/Periodo2003/PDF2003/TP2003/ 01 marzo2003/ tp012/0675-D-02pdf (Accessed 25 April 2005).

224 Lofrano EG. Proposed Legislation:"'Prohibición de fumar en oficinas públicas". Lower House; 4 Jun 2003. hitp://www1.hcdn.gov.ar/ dependencias/dsecretaria/ Periodo2003/PDF2003/TP2003/ 04junio2003/ tp065/2332-D-03pdf (Accessed 25 April 2005)

225 Oviedo AB, et al. Proposed Legislation:"'Prohibición del uso de términos engañosos en productos $\mathrm{y} / \mathrm{o}$ publicidades del tabaco". Lower House; 19 Jun 2003. http://wwwl.hodn.gov.ar/dependencias/dsecretaria/ Periodo2003/PDF2003/TP2003/04junio2003/tp076/2786-D-03pdf (Accessed 25 April 2005).

226 Oviedo AB, et al. Proposed Legislation:"Modificaciones a la ley 23.344, sobre fumar es periudicial a la salud, con relación a los envases de productos destinados a fumar, publicidad y otras cuestiones conexas" Lower House; 2 Jul 2003. http://wwwl.hcdn.gov.ar/dependencias/ dsecretaria/ Periodo2003/PDF2003/TP2003/05julio2003/ tp085/3050D-03pdf (Accessed 25 April 2005).

227 Correa JC. Proposed Legislation:"Prohibición de toda forma de publicidad o patrocinio de tabaco, cigarrillos, cigarros $\mathrm{u}$ otros productos destinados a fumar, por cualquier medio". Lower House; 20 Aug 2003. http:// www1.hcdn.gov.ar/dependencias/dsecretaria/ Periodo2003/PDF2003/ TP2003/06agosto2003/ tp1 18/3855-D-03pdf (Accessed 25 April 2005)

228 Baladrón MJ. Proposed Legislation:"Prohibición del hábito de fumar en espacios públicos y privados de acceso al público". Lower House; 23 Sep 2003. http://wwwl.hodn.gov.ar/dependencias/dsecretaria/ Periodo2003/PDF2003/TP2003/07setiembre2003/ tp1 43/4483-D03pdf (Accessed 25 April 2005).

229 Martínez SV. Interview with Ernesto M Sebrié. In:Buenos Aires, Argentina, 2003.

230 Molinari MA. Interview with Ernesto M Sebrié. In:Buenos Aires, Argentina, 2003.

231 Neri AC, et al. Ley Nacional sobre el Tabaquismo. Lower House; 14 Jul 2004. http://wwwl.hcdn.gov.ar/dependencias/dsecretaria/ Periodo2004/PDF2004/TP2004/05julio2004/ tp092/4300-D-04pdf (Accessed 25 April 2005).

232 Shibuya K, Ciecierski C, Guindon E, et al. WHO Framework Convention on Tobacco Control: development of an evidence based global public health treaty. BMJ 2003;327:154-7.

233 Framework Convention Alliance. Alliance Bulletin, Geneva; February 18 , 2003 Report No.37.http://fctc.org/bulletin/Issue_37.pdf.

234 Anon. "Antipremio" para la Argentina en la reunión mundial antitabaco. Los campeones del "Cenicero Sucio". Página 1220 Feb, 2003; Sec.Sociedad. http://www.paginal 2web.com.ar/diario/sociedad/3 16782-2003-2-20.html (Accessed 25 April 2005)

235 Ferrari A. Hacia Ginebra con una posición ultra light. Página 1215 Feb, 2003; Sec.El País. http://www.paginal 2web.com.ar/diario/elpais/116646-2003-2-15.html (Accessed 25 April 2005).

236 Environics Research Group. Public support for international efforts to control tobacco: a survey in five countries. Toronto: Environics Research Group Ltd, October 2001, http://erg.environics.net/english/5countriesenglish.pdf.

237 Ministerio de Salud. Presidencia de la Nación. Jornadas Internacionales sobre Control del Tabaco. Implicaciones del Convenio Marco para Argentina y el MERCOSUR. Buenos Aires, 2003.

238 Proposed Legislation:"Proyecto de Ley Ratificando el Convenio Marco para el Control del Tabaco" Falco LA. Senate; 2 Oct, 2003.
239 Martínez SV. Proposed Legislation:"Aprobación del Convenio Marco de la Organización Mundial de la Salud -OMS- para el Control del Tabaco". Lower House; 31 Oct 2003. http://wwwl .hcdn.gov.ar/dependencias/ dsecretaria/ Periodo2003/PDF2003/TP2003/08octubre2003/tp170/ 5254-D-03pdf (Accessed 25 April 2005).

240 Convenio Marco de la Organización Mundial de la Salud- OMS- para el Control del Tabaco, adoptado en Ginebra, Suiza, el 21/05/2003. Kirchner N, Fernández A, Bielsa R, González García G. Senate, 2004.

241 Unión Antitabáquica Argentina. Buenos Aires: UATA; 14 Nov, 2004 Report No. : 41, http://www.uata.org.ar/novedades/ALDIA/Uata41.doc (Accessed 25 April 2005).

242 Unión Antitabáquica Argentina. Buenos Aires: UATA; 29 Nov, 2004 Report No. : 42, http://www.uata.org.ar/novedades/ALDIA/Uata42.doc (Accessed 25 April 2005).

243 Comisión de Seguimiento y Control de la Implementación del Convenio Marco. Lopez Arias ME, Jenefes GR, Puerta FR, Escudero SM. Senate; 26 Oct, 2004.

244 Ballatore L. Promesa de inversiones: acuerdo de una estatal china con una cooperativa jujeña. US\$20 millones para una tabacalera. Clarín 7 Nov, 2004; Sec.El país. http://old.clarin.com/diario/2004/11/07/elpais/p01403.htm (Accessed 25 April 2005)

245 Anon. Quiere dejar de fumar? Clarín 5 Nov, 1979.

246 Daino L. Interview with Ernesto M Sebrié. In:Buenos Aires, Argentina, 2003.

247 Anon. Report on 6th World Conference on Smoking and Health, Tokyo, November 9-12, 1987 Part I. Nov 1987. Bates No. TIMN0448463/8710. Minnesota AG. http://legacy.library.ucsf.edu/tid/kbu42foO.

248 CLACCTA. May-Jun, 1988 Report No. 3

249 Perazzo DL. Interview with Ernesto M Sebrié. In:Buenos Aires, Argentina, 2003.

250 Abdala V. Has recorrido un largo camino, vicioso del humo. Los cigarrillos ya casi no se publicitan por la televisión en la Argentina. Página 122 Feb, 2002;Sec. Espectáculos. http://www.paginal 2web.com.ar/diario/ espectaculos/6-1429-2002-2-2html (Accessed 25 April 2005).

251 Bassani L. Apartada de la TV, la publicidad de cigarrillos se concentra en los kioscos "fashion". Clarín 11 Dec, 2003;Sec.Marketing. http:// old.clarin.com/diario/2003/12/11/t-673914.htm (Accessed 25 April 2005).

252 Muggli ME, Hurt RD, Blanke DD. Science for hire: a tobacco industry strategy to influence public opinion on secondhand smoke. Nicotine Tob Res 2003;5:303-14.

253 Assunta M, Fields N, Knight J, et al. "Care and feeding": the Asian environmental tobacco smoke consultants programme. Tobacco Control 2004;13(suppl II):ii4-12.

254 Barnoya J, Glantz SA. The tobacco industry's worldwide ETS consultants project: European and Asian components. Eur J Public Health, 2005; doi: 10.1093/eurpub/cki044

255 Assunta M, Chapman S. Industry sponsored youth smoking prevention programme in Malaysia: a case study in duplicity. Tobacco Control 2004; 13(suppl I):iii37-42.

256 Fichtenberg CM, Glantz SA. Youth access interventions do not affect youth smoking. Pediatrics 2002;109:1088-92.

257 Glantz SA. Preventing tobacco use - the youth access trap. Am J Public Health 1996;86:156-8.

258 Glantz SA. Limiting youth access to tobacco: a failed intervention. J Adolesc Health 2002;31:301-2.

259 Ling PM, Landman A, Glantz SA. It is time to abandon youth access tobacco programmes. Tobacco Control 2002;11:3-6.

260 Fichtenberg CM, Glantz SA. Association of the California Tobacco Control Program with declines in cigarette consumption and mortality from heart disease. N Engl J Med 2000;343:1772-7.

261 Barnoya J, Glantz S. Association of the California tobacco control program with declines in lung cancer incidence. Cancer Causes Control 2004; 15:689-95.

262 Goldfarb LMCS. Government Leadership in Tobacco Control: Brazil's Experience. In: De Beyer J, Brigden LW, eds. Tobacco control policy. Strategies, successes, and setbacks. Washington DC: World Bank \& Research for International Tobacco Control 2003, 38-70.http:// wwwl.worldbank.org/tobacco/pdf/2850-Ch03.pdf.

263 Cavalcante T. [The Brazilian experience with tobacco control policies]. Salud Publica Mex 2004:46:549-58.

264 Law 10.167 [Restrictions to the use of - and publicity referring to - smoking products, alcoholic beverages, medicines, therapeutic treatments and pesticides]. 27 Dec 2000. http://www.anvisa.gov.br/eng/tobacco/ aw 10.167.htm (Accessed 26 April 2005).

265 Resolution - RDC n 46 [Establish the maximum levels allowed of tar, nicotine and carbon monoxide present in the mainstream smoke of cigarettes commercialized in Brazil]. 28 Mar 2001. http://www.anvisa.gov.br/eng/ tobacco/rdc 46.htm (Accessed 26 April 2005)

266 Resolution - RDC n• 335 [Health warnings and images on cigarette packages]. 21 Nov 2003. http://www.anvisa.gov.br/eng/legis/resol/ 335_03rdc.htm (Accessed 26 April 2005). 